\title{
Analysis on Determinants of Adoption of Improved Wheat Technology in Liben Jewi District, Oromia Region, Ethiopia
}

\author{
Milkias Dawit Kebede \\ Ethiopian Institute of Agricultural Research/EIAR/, Ambo ARC, Ambo, Ethiopia
}

\section{Email address:}

mkdave04@gmail.com

\section{To cite this article:}

Milkias Dawit Kebede. Analysis on Determinants of Adoption of Improved Wheat Technology in Liben Jewi District, Oromia Region, Ethiopia. International Journal of Applied Agricultural Sciences. Vol. 6, No. 3, 2020, pp. 36-43.. doi: 10.11648/j.ijaas.20200603.12

Received: April 21, 2020; Accepted: May 7, 2020; Published: May 28, 2020

\begin{abstract}
Ethiopia is the second largest wheat producer in sub-Saharan Africa, after South Africa. In Ethiopia, wheat ranks fourth in total cultivated area and production. This study applied logit regression to examine determinants of adoption of improved wheat varieties in the Liban jewi district of West Showa zone Oromia region Ethiopia. The objective of the study is to analyze determinants that affect adoption of improved wheat varieties which exert significant influence on the adoption behavior of sample respondents in the study area. A total of 154 sample respondents drawn from 6 PAs of the district included in the survey. The model result shows that the adoption of improved wheat varieties by respondents in the study area was positively and significantly affected by farm size, livestock ownership, extension contact and access to credit, whereas, age of respondents, distance from market and distance from farmers training center had negatively and significantly influenced adoption of improved wheat varieties in the study area. The result underscores the need for research and extension programs to be sensitive to the needs of farmers when developing and disseminating technologies that are relevant to their agro-ecologies.
\end{abstract}

Keywords: Adoption, District, Logit, Technology

\section{Introduction}

Agricultural technology is among the most impactful area of modern technology; play a key role in enhancing agricultural yield, poverty reduction and in improving national food security [29]. It creates spillover effects to the remaining sectors However, production and productivity of the agricultural sector is low in developing countries due to low technological adoption and techniques among others [2]. Agricultural production is the bases for domestic food consumption and one of the mitigating mechanisms for the problem of food insecurity in Ethiopia.

The government of Ethiopia has developed different ways of agricultural production strategy to enhance the productivity of smallholders, among various approaches Agricultural Development Led Industrialization (ADLI) is the one that had supposed to exploit the existing agricultural potential of the country, its prominence is for enhancement of productivity of the smallholder and industrialization through utilization of the domestic raw materials by using improved labor technologies. Cereals are the major food crops both in terms of the area coverage and volume of production and accounts for $95 \%$ of agricultural production in Ethiopia and contributed $86.68 \%$ of the grain production. Maize, wheat and teff are the most important cereals in terms of volume accounting for a total of $77 \%$ of all cereal production [6], According to the [7] reports maize, teff, wheat and sorghum have made $26.8 \%, 16.76 \%, 15.81 \%$ and $16.2 \%$ of the grain production respectively.

Wheat is the most widely grown cereal crop in the world, with an ever-increasing demand. It plays a fundamental role in food security, and a major challenge is to meet the additional requirements with new cultivars and improved cropping technologies. Wheat is a primary source of calories and protein for 4.5 billion people in more than 100 countries [22]. Wheat is grown on over 240 million hectares worldwide, this shows area coverage of wheat is more than any other crops, and over 80 percent of this land is located in the developing world. Therefore, improving yields of this crop is very important since the diets of human beings on every continent rely on this staple crop. As per FAOSTAT [13] now a day wheat production has shown increasing rate due to increase in area coverage but, productivity in a unit area of land is not as expected. Same data shows that for the 
last five years wheat production trend has shown an increasing rate during the year of 2009 to 2014 world wheat production was $685.6,651.4,704.1,674.9,713.2$ and 220 million metric tons respectively. To this end, the average production of wheat has been increasing by 1.16 percent in the world. According to the author [3] even if the area coverage of wheat in Ethiopia is higher, the mean national yield is (2.1ton/ha) 19 percent and 49 percent below the mean yield for Africa and the World respectively. This relatively low mean national yield may be partially attributed to the low level of adoption of improved wheat production technologies.

Liben jewi district is one of the major wheat growing areas in West Showa zone of Oromia regional state. They are known for cultivation of many crops which include, among others, cereals such as teff, wheat, Maize, barley, pulses and etc. According to the author [8] the region shares wheat production about $51.32 \% \quad(897,188$ ha) and $55.5 \%$ $(26,852,876.15 \mathrm{qt})$ of the total area and production respectively. Of the total regional wheat production most of it is coming from West showa and other zones of the region. Even if the province and specifically the district has endowed with potential area for wheat production the lower production hinders the living standard of the household [5]. Therefore, to improve the living standard of smallholders in a sustainable way, introducing improved methods of agricultural practice, advising smallholders to use improved wheat varieties, fertilizers and chemicals are the basic ones.

In Liben jewi district, there was no empirical information so far on the adoption of improved wheat technologies. Therefore, improving agricultural productivity and development and thereby improving smallholder farmers' livelihood requires increased efforts in influencing farmer to use yield enhancing agricultural technologies. Therefore, study on the different socioeconomic, institutional and psychological factors that influence the adoption of wheat technology is useful for technology development and design of policies and strategies that foster adoption of wheat technologies to manage up the livelihood of the district. Hence, the objective of the study was designed to examine the factors that affect adoption of wheat technology in the study area to fulfill the existing knowledge gap.

\section{Empirical Literature Review}

Ethiopia is the second largest wheat producer in subSaharan Africa, after South Africa. Wheat is among the most important crops in Ethiopia, ranking fourth in total cereals production $16 \%$ next to maize, sorghum and teff [9]. It is grown as a staple food in the highlands at altitudes ranging from 1500 to 3000 m.a.s.l. nearly all wheat in country is produced under rain-fed conditions predominantly by small farmers. A few governments owned large-scale (state) farms and commercial farms also produce wheat. Despite the recent expansion, Ethiopia falls short of being self-sufficient in wheat production, and is currently a net importer of wheat grain. Wheat ranks fourth in terms of area production and yield among food crops. Production of wheat increased from $2.2(000 \mathrm{~T})$ in 2004/2005, [4] to $2.8(000 \mathrm{t})$ in 2010/2011 an increase of $31 \%$. However, the share of wheat in total cereal area decreased $12.4 \%$ over the same period, mainly due to a shift in cropping patterns towards sorghum. Wheat yield in Ethiopia is also lagging behind other major producers in Africa: average yield was 1.68 ton/ ha during the same period, about $32 \%$ and $39 \%$ below Kenyan and South African averages, respectively [13]. At present, wheat is produced solely under rain fed conditions. The author [12] result indicated that from explanatory variables included in the model most of them were found to be significant. Farm size, extension contact, and distance from main market were the most important factors influencing adoption and intensity of use of improved sweet potato varieties. In the study the logit model results revealed that crop land holding size, number of livestock owned and radio ownership have a significant and positive influence on the adoption decision of improved sorghum varieties, whereas age, type of house owned and distance to input market have a significant and negative influence on the adoption decision [21]. However, family size and education do not have statistically significant influence on adoption decision. The study output revealed that variables such as farm size, livestock, ownership of oxen, availability of fertilizer on time, availability of cash for down payment, access to formal credit, ownership of radio and attending on demonstration were positively and significantly influenced [27].

The research of [16] model result confirmed that education, extension contact, forestry training, age, agro forestry practice, (TLU) were variables influenced adoption and intensity of new technology. Similar study carried out by [26] proximity to markets showed positive relationships with the use of modern cultivar wheat seed at the farm level. In [11] indicated that household annual income, access to market, research and extension service, and perception of improved tef variety were important variable influencing adoption and intensity of use of tef technology. Study conducted by author [24] result of econometric model indicated that education, access to credit, participation in extension events were important variables which had positive and significantly influenced adoption and intensity of adoption of improved Onion production technology. The results of the author [20] indicated that perception of households, participation in extension events, frequency visit, education, social participation were important variables which had positively and significantly influenced adoption and intensity of adoption of old Coffee stumping Technology.

\section{Methodology of the Study}

\subsection{Description of the Study Area}

The study was conducted in Liban jewi district of West Showa zone, Oromia region Ethiopia which is located about $161 \mathrm{~km}$ west of Capital city of Ethiopia Addis Ababa and 47 $\mathrm{km}$ west direction of Ambo Town. The district capital is 
Babichi city. Geographically, the city is located at $8^{\circ} 58^{\prime} 19^{\prime \prime}$ $\mathrm{N}$ latitude and $37^{\circ} 32^{\prime} 37^{\prime \prime} \mathrm{E}$ longitudes with an average elevation of 2293 meters above sea level. This district is bounded with Toke kutaye in the East, Chelia in the West, Midakegn in North, and Jibat in the South. The district has annual rainfall of $900-1800 \mathrm{~mm}$. The annual temperature ranges from $16-28^{\circ} \mathrm{C}$. Administratively, the district made up of 16 kebeles (15 rural and 1 urban kebeles). The total population number of the study area is $70820(35,376$ males and 35,444 female). There are 9155 households with 8339 male and 816 female headed households, respectively in the district. The land use pattern of the district shows that from the total of 32,837 ha, 18,537 ha is cultivated land; 8548 ha is covered with forest, 5467 ha is grazing land and 285 ha with used for other social purposes. The major crops produced in the district are Teff, wheat, Maize, barley and pulse crops [28].

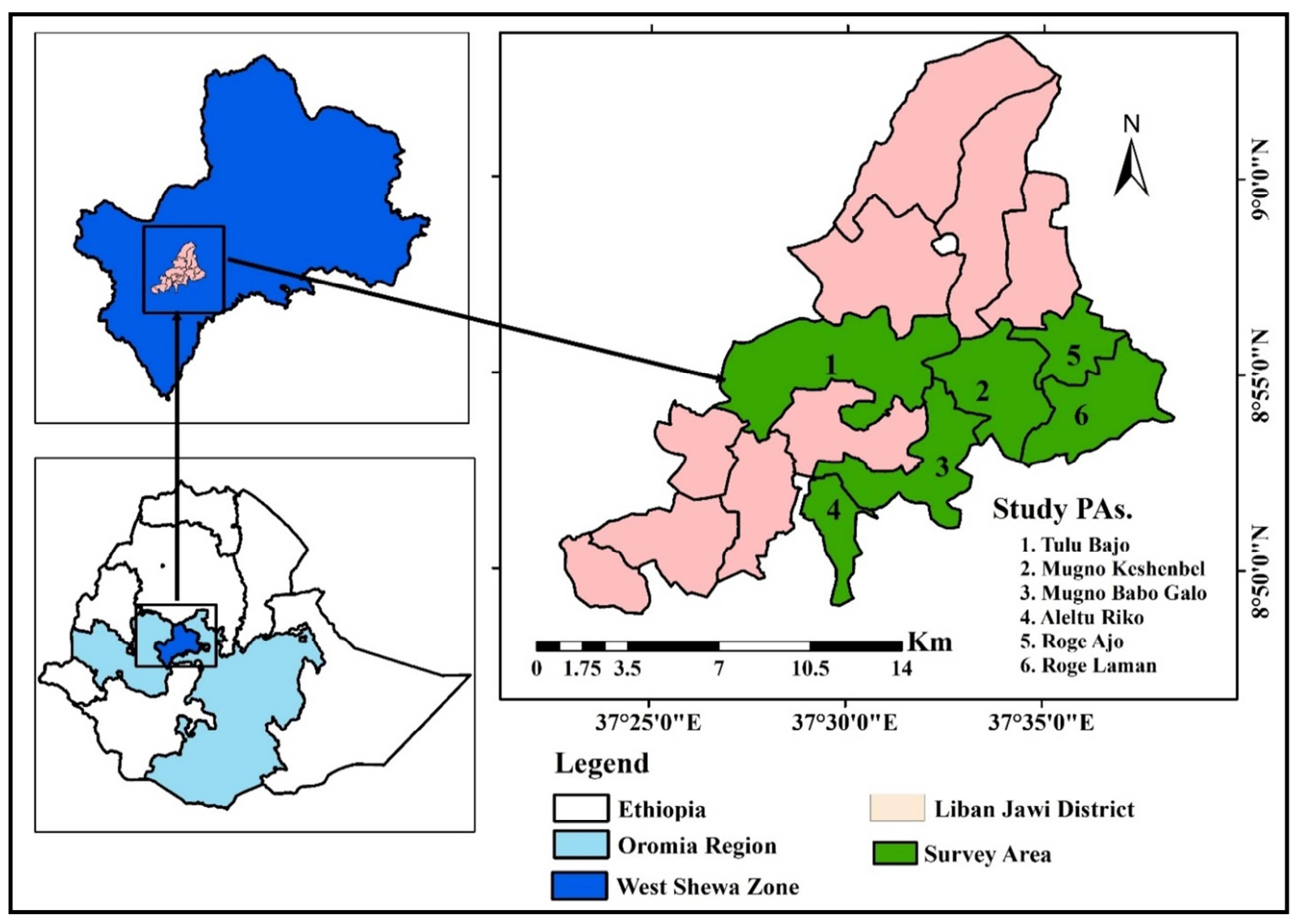

Figure 1. Map of Study Area.

\subsection{Sampling Procedure, Sample Size and Analysis}

The study district was selected purposively based on accessibility, potential to wheat production and representativeness of the Zone. The district consists 16 Peasant Associations (PAs). Out of these, 6 PAs were selected by using simple random sampling techniques. To give equal chance in selection of study units from each concerned PA, probability proportional to size (PPS) was applied. Finally, through systematic sampling techniques 154 sample respondents were selected from each PA for both adopters and non-adopters. The farmers were categorized as adopters when they adopted the recommended improved wheat technology (either of three improved varieties being productive in the area, namely Okolcha, Dendea and Kingberd).

The sample keeping the proportion to each kebeles were selected by using Yamane (1967) sample size formula and 8\% Precision Level Where Confidence Level is 95\%.

$$
\mathrm{n}=\frac{N}{1+N(e)^{2}}=\frac{9155}{1+9155(0.08) 2} \approx 154
$$

Where $\mathrm{n}$ is the sample size for the study, $\mathrm{N}$ is the total households of the study area which is 9155 , e is the maximum variability or margin of error or which is 0.08 in this study, 1 is the probability of the event occurring. The sample size from each kebeles' was determined based on their proportion to total share of households residing in each kebeles.

Table 1. Sample size determination.

\begin{tabular}{llll}
\hline No. & Sample kebeles & Households & Sample size \\
\hline 1 & Tulo bajo & 925 & 35 \\
2 & Mugno kashanbal & 828 & 32 \\
3 & Mugno babo galo & 807 & 31 \\
4 & Aleltu riko & 369 & 14 \\
5 & Roge ajo & 325 & 12 \\
6 & Roge leman & 777 & 30 \\
& Total & 4031 & 154 \\
\hline
\end{tabular}

Source: Author's compilation, 2019. 
Method of Data Collection: The main source of data for the study was primarily field survey which focused on data related to socioeconomic, institutional and demographic characteristics of the respondents, and other related information that were essential for the research purpose. The data were collected using quantitative approach by means of household and one-on-one contact survey. The secondary data sources was collected from published and unpublished materials, which include books, journals, scientific research works and office records.

Analysis: In this study, descriptive statistics were mainly applied. Binary logistic regression was incorporated to analyze relationships between a dichotomous dependent variable and explanatory variables. The logistic regression was fitted employing method of wheat technology adoption as dependent variable and the listed demographic, institutional and socioeconomic variables as independent variables which is assumed to determine wheat technology adoption. The variable is binary, taking values of one if the farmer adopts and zero otherwise. However, the explanatory variables are categorical, continuous and dummy. The justification for using logit is its simplicity of calculation and that its probability lies between 0 and 1 .

Moreover, its probability approaches 0 at a slower rate as the value of independent variable gets smaller and smaller, and the probability approaches 1 at a slower and slower rate as the value of the independent variable gets larger and larger [14].

Table 2. Definition of the variables and units of measurement.

\begin{tabular}{|c|c|c|}
\hline Variables & Type & Descriptions of the Variables \\
\hline Dependent Variable & \multirow{3}{*}{ Dummy } & \multirow{3}{*}{ This takes the value of 1 for adopter farmers, 0 otherwise. } \\
\hline Adoption of IWV & & \\
\hline Independent variables & & \\
\hline Age of respondents & Continuous & Age of household head (year). \\
\hline Education level & Categorical & Illiterate, 2. Read and write, 3. Primary school, Secondary school and 5. College \\
\hline Farm size & Continuous & Cultivated area in hectare \\
\hline Access to credit & Dummy & 1 , If the farmer has access to credit; 0 , otherwise \\
\hline Farm income & Continuous & Average annual earnings of the farmers /ETB/ \\
\hline Extension service & Dummy & 1, If the farmer has contact with Extension agents; 0, otherwise \\
\hline Access to field day & Dummy & 1 if the farmers participated on field day 0 , otherwise. \\
\hline Labor availability & Continuous & Labor availability in man equivalent \\
\hline Market distance & Continuous & Distance of the respondent's from the market $(\mathrm{km})$. \\
\hline Distance to FTC & Continuous & Distance of the respondents' from FTC in km \\
\hline Cooperatives/Union & Dummy & 1 , if the farmers membership of any cooperatives/union, 0 , otherwise \\
\hline Training & Dummy & 1 if the farmers participated on agri. training 0 , otherwise. \\
\hline
\end{tabular}

Source: Author's compilation, 2019.

\section{Results and Discussion}

\subsection{Descriptive Statistics Results}

Improvement in production and productivity of a given crop depends, among other things, on presence and use of better and improved varieties and related agronomical practices. In line with this objective, a lot of efforts have been made by the research system to generate improved varieties with practical packages which were recommended by the researchers and were being promoted by extension systems, such as use of improved varieties, land preparation, application of fertilizer, application of chemicals, weed management, seeding rate, planting space etc. and as a result, many varieties have been released. Among the released wheat varieties, Okolcha, Dendea and Kingberd were introduced to the farming community through government like research center, MoA and other non-governmental organizations. In the study area wheat is an important crop used as source of cash income and for household food consumption.
Table 3. Types of improved wheat varieties adopted by sample respondents.

\begin{tabular}{lll}
\hline Improved Wheat varieties & Frequency & Percentage \\
\hline Okolcho & 31 & 44.3 \\
Dendea & 22 & 31.4 \\
Kingberd & 17 & 24.3 \\
Total & 70 & 100 \\
\hline
\end{tabular}

Source: Author's compilation, 2019.

Regardless of such intervention, however, adoption of improved wheat varieties in the study area is still low. Having these facts the adoption level in the study area on improved wheat technology was indicated in the table below.

Table 4. Percentage of sample households by level of adoption $(N=154)$.

\begin{tabular}{lll}
\hline Adoption categories & No. of sample households & Percentage \\
\hline Adopter & 70 & 45.5 \\
Non-adopter & 84 & 54.5 \\
Total & 154 & 100 \\
\hline
\end{tabular}

Source: Author's compilation, 2019.

From table 4, data set contains 154 farm households and 
of these, about $70(45.5 \%)$ households were adopters and about $84(54.5 \%)$ household heads were non-adopters. Farmers who did not grow improved wheat variety were considered as non-adopters and while the farmers who grow at least one of the improved wheat varieties during the 2018 cropping season with some of the recommended agronomic practices (improved variety, seed rate, and fertilizer application rate) were taken as adopters. In this study, a total of 13 independent variables were identified. From continuous variables farm income, distance from main market and distance from FTC result revealed significant association at $1 \%$ significance level with the adoption of improved wheat varieties, and variables such age of the sample respondents, labour availability, farm size and livestock ownership result had not statistically significant relation with the adoption decision in the study area (Table 5). Participation in cooperative/union, access to credit and extension service from dummy variables had statistical significant at $1 \%$ and $5 \%$ level of significance with adoption relation of sample respondents, whereas sex of the household heads, education level and participating in field day result show not statistically significant relation with the adoption of improved wheat varieties among adoption categories in the study area (Table 6). Summary of the overall descriptive results of this study is presented in tables 5 and 6 below.

Table 5. Descriptive statistics for some selected continuous variable.

\begin{tabular}{|c|c|c|c|c|c|c|}
\hline \multirow{3}{*}{ No. } & \multirow{3}{*}{ Variables } & \multicolumn{3}{|c|}{ Mean of adoption category } & \multirow{3}{*}{ t-value } & \multirow{3}{*}{ P-Value } \\
\hline & & Adopters & Non Adopters & Total Sample & & \\
\hline & & $(\mathrm{N}=70)$ & $(\mathrm{N}=84)$ & $(\mathrm{N}=154)$ & & \\
\hline 1 & Age of household & 47.95 & 78.3 & 48.2 & -0.40 & 0.26 \\
\hline 2 & Labor availability & 2.56 & 2.68 & 2.62 & 0.60 & 0.54 \\
\hline 3 & Farm size & 1.12 & 1.08 & 1.1 & -1.25 & 0.21 \\
\hline 4 & Farm Income & 9131.8 & 6362.4 & 7621.2 & -5.50 & $0.00 * * *$ \\
\hline 5 & Livestock & 6.6 & 6.2 & 6.4 & -0.84 & 0.40 \\
\hline 6 & Distance to Market & 8.9 & 13.07 & 11.18 & 4.85 & $0.00 * * *$ \\
\hline 7 & Distance to FTC & 2.89 & 4.73 & 3.89 & 10.78 & $0.00 * * *$ \\
\hline
\end{tabular}

Source: own survey data, 2019. ***, denote significant at $1 \%$, levels of significance respectively.

Table 6. Descriptive analysis for some of the dummy and categorical variables.

\begin{tabular}{|c|c|c|c|c|c|c|c|c|}
\hline \multirow{3}{*}{\multicolumn{2}{|c|}{ No. Variables }} & \multirow{3}{*}{ Category } & \multirow{2}{*}{\multicolumn{2}{|c|}{$\begin{array}{l}\text { Adopters } \\
(\mathbf{N}=70)\end{array}$}} & \multirow{2}{*}{\multicolumn{2}{|c|}{$\begin{array}{l}\text { Non adopters } \\
(\mathrm{N}=\mathbf{8 4}) \\
\end{array}$}} & \multirow{3}{*}{$\mathbf{X}^{2}$} & \multirow{3}{*}{ P-Value } \\
\hline & & & & & & & & \\
\hline & & & $\mathbf{N}$ & $\%$ & $\mathbf{N}$ & $\%$ & & \\
\hline \multirow[t]{2}{*}{1} & Sex of HHHs & Female & 9 & 12.86 & 12 & 14.29 & 0.06 & 0.79 \\
\hline & & Male & 61 & 87.16 & 72 & 85.71 & & \\
\hline \multirow[t]{3}{*}{2} & Education level & Illiterate & 27 & 38.6 & 22 & 26.19 & 2.84 & 0.42 \\
\hline & & Read \& write & 26 & 37.1 & 44 & 44.05 & & \\
\hline & & Primary & 15 & 21.4 & 21 & 25 & & \\
\hline \multirow[t]{2}{*}{3} & Coop/Union & No & 56 & 80 & 50 & 52 & 7.46 & $0.006 * * *$ \\
\hline & & Yes & 14 & 20 & 34 & 48 & & \\
\hline \multirow[t]{2}{*}{4} & Extension service & No & 1 & 1.43 & 10 & 11.9 & 7.6 & $0.05 * *$ \\
\hline & & Yes & 69 & 98.6 & 74 & 88.1 & & \\
\hline \multirow[t]{2}{*}{5} & Access to credit & No & 3 & 4.29 & 55 & 65.48 & 60.8 & $0.00 * * *$ \\
\hline & & Yes & 67 & 95.7 & 29 & 34.52 & & \\
\hline 6 & Field day & No & 21 & 30 & 30 & 35.71 & 0.56 & 0.45 \\
\hline
\end{tabular}

Source: own survey data, 2019. ***,** denote significant at $1 \%$ and $5 \%$ levels of significance respectively.

\subsection{Determinants that Affect Adoption of Improved Wheat Technology: Logistic Regression}

Each of the explanatory variables hypothesized to potentially influence adoption of improved wheat varieties was fitted into a logistic model (Table 7), and their individual contributions to the model were assessed on the basis of changes in deviance. Variables contributing significantly to the model were selected and the main effect and interactions were further investigated. The goodness of fit associated with adding each variable to the model was assessed by comparing the resulting change in deviance due to the addition of each variable in the model with the corresponding chi-square value.
As per the table 7, the logit model results used to analysis determinants of adoption decision of improved wheat technology. The result of the model shows that the explanatory variables: age, distance from market and distance from FTC were found negatively and significantly influence adoption decision of improved wheat technology, whereas, farm size, livestock, extension contact and credit service, were found positively statistical significant with adoption of improved wheat technology at different significance level. The detail results of statistically significant explanatory variables of adoption of improved wheat varieties are explained as follows.

Age of the respondents: The result indicates that age of household head significantly influenced the probability of 
adopting high yielding teff varieties at 5\% significance level. The model results show that as the age of the household head increases by one year, the odds ratio in favor of not adopting increases by $0.024 \%$. The main reasons given for older people being less likely to adopt new technologies is that they are said to be less receptive to new ideas and are less willing to take risks. This means there may be a need to review methods of technology dissemination used in the intervention programme to ensure that they are attractive to both young and old farmers. This result confirms the findings of $[1,15,17]$.

Livestock: The model result indicates that number of livestock unit affected positively and significantly the probability of adoption of improved wheat varieties at $10 \%$ significance level. This result shows that those farmers with large number of tropical livestock units are more likely to adopt improved wheat technology than those who own small number of TLUs. Other things held constant, the odds ratio for number of TLU shows that, as the number livestock units increases by one TLU, the odds ratio in favor of adopting improved Wheat technology increases by a factor of 0.048 . This result is in line with results of a prior study conducted by [25].

Access to credit: The model result indicates, this variable had positively and significantly influenced the likelihood of adoption of improved wheat technology at 1 percent significance level. From this result it can be stated that those farmers who have access to formal credit from any governmental and non-governmental organization are more likely to adopt improved wheat technology than those who have no access to formal credit. The odds ratio indicated in the model with regard to this variable that, other thing being held constant, the odds ratio in favor of adopting improved wheat variety increases by a factor of 0.56 as farmers gets access to credit.

Farm size: influenced the adoption of improved wheat varieties positively and significantly at 1 percent significance level. The odd ratio result indicate that favor for adopting of new technology as the farm size increased by one hectare adoption of wheat technology was increased by the rate of 1 percent. The implication is that farmers with large farm size are more likely to adopt the improved wheat varieties than those farmers who have small land size. This finding is confirms the findings of the studies $[10,19,18,23]$, who found positive effects of farm size on adoption of the new technology.

Distance to the market: has a strong and negative effect on adoption of improve wheat varieties at $1 \%$ significance level. The result indicates that a kilometer increase in distance from market leads to a decrease in the likelihood of adoption of wheat technology by a factor of 0.13 , other factors kept constant. The negative association suggests that the likelihood of adopting improved wheat varieties declines as the distance from market center increases. This result is in line with the findings of other similar studies [1].

Distance from FTC: Farmers residing at a farther distance from FTC were found not to be better adopters of wheat technology compared to those residing at a distance located closer to an FTC. A kilometer increase in farmers' distance from farmers training centers/FTC results in a decrease in adoption of wheat technology by a factor of 0.018 , keeping other factors constant and it is negatively and statistically significant at 5 percent level. The closer the sample respondents to farmers training center/FTC/ the better it would be to access information about agricultural technologies, visiting demonstration and participating field day hence is positively related to technology adoption.

Extension Service: Result of the finding indicated that extension contact was positive and statistically significant at $5 \%$ with adoption of improved wheat varieties. The result indicate that other things held constant, the odds ratio in favor of decision on adoption of improved wheat technology was increased by a factor of 0.019 percent for a unit increase of extension services. The positive and significant coefficient of the extension contact variable indicate that provision of regular and frequent extension services by development agents within the farmer development center plays a fundamental role in the dissemination and adoption of a technology. The estimates of parameters of the variables expected to influence adoption of improved wheat varieties are displayed on table 7 below

Table 7. The maximum likelihood estimates of the logit model.

\begin{tabular}{|c|c|c|c|c|c|}
\hline Variables & Coefficient & Std. Err & Wald- statistic & Sig. level & Odds ratio \\
\hline Age of respondents & -0.1009 & 0.9058 & -2.18 & $0.03 * *$ & -0.0237 \\
\hline Sex of household & 0.1998 & 0.9058 & 0.22 & 0.83 & 0.0459 \\
\hline Education level & 0.4562 & 0.3654 & 1.25 & 0.21 & 0.107 \\
\hline Farm size & 4.3008 & 1.6555 & 2.6 & $0.009 * * *$ & 1.0094 \\
\hline Livestock & 0.2065 & 0.1109 & 1.86 & $0.06^{*}$ & 0.0485 \\
\hline Farm income & 0.000113 & 0.0001 & 1.13 & 0.26 & 0.000026 \\
\hline Labour availability & -0.0447 & 0.2188 & -0.21 & 0.84 & -0.0105 \\
\hline Distance to FTC & -0.3971 & 0.1819 & -2.18 & $0.03 * *$ & -0.0932 \\
\hline Extension service & 0.824 & 0.408 & 2.02 & $0.04 * *$ & 0.1934 \\
\hline Distance to Market & -0.5952 & 0.1622 & -3.67 & $0.00 * * *$ & -0.1397 \\
\hline Access to credit & 3.2606 & 0.9866 & 3.31 & $0.001 * * *$ & 0.5999 \\
\hline Field day & -0.4933 & 0.6429 & -0.77 & 0.44 & -0.1175 \\
\hline cons & 0.67054 & 3.9092 & 0.17 & 0.86 & \\
\hline
\end{tabular}

No. of observation=154; Wald $\chi 2(13)=124.40 * * *$; Prob $>\mathrm{Chi}^{2}=0.00$; Pseudo $\mathrm{R}^{2}=0.5862$;

Log likelihood $=-43.905545 ; * * *, * * *$ denote significant at $1 \%, 5 \%$ and $10 \%$ levels of significance respectively. 


\section{Conclusion and Recommendation}

This paper considered the determinants of adoption of improved wheat varieties in Liban jewi district, West Showa zone of Oromia region Ethiopia using data obtained from a sample over 154 sample respondents. The logit model results indicate that determinants of adoption of improved wheat varieties in the study area showed that adoption is significantly related to age of the respondents, farm size, distance from FTC, livestock ownership, Distance from market, credit service and contact with extension agents.

The agricultural research system should put more emphasis on solving the problems of wheat producers and increase the frequency of release of new varieties that resist diseases and pests, yield well, and tolerate drought. To make the research effort more successful, seed of newly developed varieties must be produced in sufficient quantities and quality for producers in the study area, the region, and the nation at large. To achieve this goal, the government must provide incentives and support to public and private seed companies, including infrastructure and credit. To increase the flow of information to farmers (and the adoption of new technologies), the extension package program needs further strengthening.

More demonstration sites for improved technologies, including wheat varieties and fertilizer application, should be organized to increase awareness of the new technologies among farmers in the study area. The contact between extension agents and farmers must be strengthened by reducing the ratio of farmers to development agents. It has been noted that with rising input prices, improved access to credit for peasant farmers has become indispensable. The formal credit system needs to address the credit constraints faced by small-scale farmers and increase awareness about the types of credit available for agricultural production.

\section{References}

[1] Asfaw, S., B. Shiferaw, F. Simtowe and M. G. Haile, 2011. Agricultural technology adoption, seed access constraints, and commercialization in Ethiopia. Journal of Development and Agricultural Economics, Vol. 3 (9), pp. 436-447.

[2] Abraham B, Araya H, Berhe T, Edwards S, Gujja B, Khadka R, Sen D, Koma Y, Sharif A, and Styger E. (2014). The system of crop intensification: Reports from the field on Improving agricultural production, food security, and resilience to climate change for multiple crops. Addis Ababa, Ethiopia.

[3] Bekele Hundie Kotu, H. Verkuijl, W. Mwangi, and D. Tanner. 2000. Adoption of Improved Wheat Technologies in Adaba and Dodola Woredas of the Bale Highlands, Ethiopia. Mexico, D. F.: International Maize and Wheat Improvement Center (CIMMYT) and Ethiopian Agricultural Research Organization (EARO).

[4] CSA (Central Statistical Authority). 1998. Statistical Abstract. Addis Ababa, Ethiopia: CSA.
[5] CSA (Central Statistical Authority) (2013): Federal Democratic Republic of Ethiopia, Agricultural Sample Survey on major crop production, Addis Ababa, Ethiopia.

[6] ATA (Agricultural Transformation Agency). 2016. Transforming agriculture in Ethiopia. Annual report 2015/2016.

[7] CSA (Central Statistical Agency). 2016. Agricultural Statistics Abstract: Agriculture". Addis Ababa, Ethiopia.

[8] CSA (Central Statistical Authority) 2018/19: The Federal Democratic Republic Of Ethiopia Central Statistical Agency Agricultural Sample Survey Volume I Report On Area And Production Of Major Crops.

[9] CSA (Central Statistical Authority) 2009. (Central Statistical Authority). Agricultural sample survey, 2008/2009 (2001 E. C) report on area and production for major crops (private peasant holdings, main season), statistical bulletin 446, Addis Ababa, Ethiopia.

[10] Chandio AA, Jiang Y, Joyo MA, et al. (2016) Impact of area under cultivation, water availability, credit disbursement, and fertilizer off-take on wheat production in Pakistan. J Appl Environ Biol Sci 6: 10-18.

[11] Daniel Tilahun, 2008. Adoption and intensity of use of Tef technology Package in Yilmana Densa District, West Gojam Zone in the Amhara Region. M. Sc.

[12] Dawit Milkias and Abduselam Abdulahi, 2018: Determinants of Agricultural Technology Adoption: The Case of Improved Highland Maize Varieties in Toke Kutaye District, Oromia Regional State, Ethiopia.

[13] FAOSTAT (2014). Crop production and trade. Rice production, importation harvested area. http://faostat.fao.org/site/567/DesktopDefault.aspx?PageID=5 67\#ancor accessed 19/may/2014.

[14] Gujarati, D. (2003). Basic Econometrics. 4th Edition. McGraw-Hill, New York. pp. 563-636.

[15] Hailu BK, Abrha BK, Weldegiorgis KA. 2014. Adoption and impact of agricultural technologies on farm income: Evidence from southern Tigray, northern Ethiopia. IJFAEC. 2 (4): 91106.

[16] Hailekiros Sisay 2007, Determinants of adoption and intensity of use of Homestead Agroforestry Practice in Hintalo-Wajerat Wereda, Southern Tigray, Ethiopia.

[17] Jaleta M, Kassie M, Marenya P. 2015. Impact of improved maize variety adoption on household food security in Ethiopia: an endogenous switching regression approach. Paper presented on Int. conference of agricultural economists, 29 th of May 2015, Milan, Italy.

[18] Leake G, Adam B (2015) Factors determining allocation of land for improved wheat variety by smallholder farmers of northern Ethiopia. J Dev Agric Econ 7: 105-112.

[19] Kebede D, Ketema M, Dechassa N, et al. (2016). Determinants of adoption of wheat production technology package by smallholder farmers: Evidences from eastern Ethiopia. Turkish J Agric-Food Sci Technol 5: 267-274.

[20] Mulugeta Arega, 2009. Determinants of intensity of adoption of old Coffee Stumping technology in Dale Wereda, SNNPRS, Ethiopia M. Sc. 
[21] Mahdi Egge, P. Tongdeelert, S. Rangsipaht and S. Tudsri, 2012. Factors affecting the adoption of improved sorghum varieties in awbare district of somali regional state, Ethiopia. Kasetsart J. (Soc. Sci). 33: 152 -160.

[22] Sanjaya, R., 2014: The world food prize, global and regional food consumption patterns and trends.

[23] Shiferaw B, Kassie M, Jaleta M, et al. Adoption of improved wheat varieties and impacts on household food security in Ethiopia. Food Policy 44: 272-284.

[24] Tadesse Adgo Mihiretu, 2008. Farmer" s evaluation and adoption of improved Onion Production package in Fogera District, south Gonder.
[25] Yishak et al, 2011: Determinants of Adoption of Improved Maize Technology in Damot Gale, Wolaita, Ethiopia.

[26] Yealembirhan, 2007; Integrating the Formal and Informal Wheat Seed Supply Systems to Improve Farmers" Access to Modern Cultivars in the North Shewa Zone of the Amhara Region, Ethiopia.

[27] Yishak Gecho, 2005: Determinants of Adoption of Improved Maize Technology in Damot Gale Woreda, Wolaita, Ethiopia.

[28] Woreda office of ARD, 2019: Activity performance reports. Liban jewi district, West showa zone, Oromia region Ethiopia.

[29] World Bank (2014). Ethiopia poverty Assessment. Document of the WB for official use only. 